\title{
Perencanaan Kombinasi Beton dengan Metode Departement of Environment (DoE)
}

\author{
Rahayu Isnin Astuti \\ Universitas Nahdlatul Ulama Blitar, Indonesia \\ Email: ayurahayuisnin@gmail.com
}

\begin{tabular}{l}
\hline Tersedia Online di \\
\hline http://www.jurnal.unublitar.ac.id/i \\
ndex.php/briliant \\
\hline Sejarah Artikel \\
\hline Diterima pada 22 November 2019 \\
Disetujui pada 30 November 2019 \\
Dipublikasikan pada 30 November \\
2019 Hal. 410-414 \\
\hline Kata Kunci: \\
\hline Metode DoE, Kombinasi Beton \\
DOI: \\
\hline http://dx.doi.org/10.28926/briliant. \\
v3i4.414
\end{tabular}

\begin{abstract}
Abstrak: Mengetahui kebutuhan air di mortar dan kebutuhan air dicampuran cor untuk menentukan kadar kuat tekan rencana, jenis semen, jenis agregat kasar yang akan digunakan, serta umur kubus beton dimana kekuatan tekan rencananya akan ditinjau, serta diperkirakan kuat tekan kubus beton untuk $\mathrm{W} / \mathrm{C}=0,5$ dapat ditetapkan. Maka kwalitas semen yang dibutuhkan dalam perencanaan dapat dihitung menggunakan data banyaknya air bebas yang diperlukan untuk setiap kubikasi beton, besarnya jumlah semen yang dihitung atas dasar jumlah air bebas dan W/C yang sebelumnya telah ditetapkan, tidak boleh kurang dari jumlah semen minimum yang disyaratkan pada kondisi "exposure" tertentu untuk menjamin ketahanan pada kondisi yang disyratkan.
\end{abstract}

\section{PENDAHULUAN}

Beton adalah suatu bahan yang mempunyai kekuatan yang tinggi terhadap tekan, tetapi sebaliknya mempunyai kekuatan relatif sangat rendah terhadap tarik. Dengan menggunakan kombinasi beton dengan baja sebagai bahan struktur, maka tegangan-tegangan tekan didalam penampang dipikulkan kepada beton, sedangkan tegangan-tegangan tarik dipikulkan kepada baja (Subiyanto, 1987)

Nilai kuat tekan beton relatip tinggi dibandingkan dengan kuat tariknya, dan beton merupakan bahan bersifat kaku (rigid). Nilai kuat tariknya hanya berkisar 9\% - 15\% saja dari kuat tekannya. Beton bertulang atau beton bertulang baja adalah komponen struktur beton dimana sebagai komponen struktural bangunan, umumnya beton diperkuat dengan batang tulangan baja sebagai bahan yang dapat bekerja sama dan mampu membantu kelemahannya, terutama pada bagian yang menahan gaya tarik. Yang bertujuan untuk menentukan kadar kuat tekan rencana, jenis semen, jenis agregat kasar yang akan digunakan, serta umur kubus beton dimana kekuatan tekan rencananya akan ditinjau, serta diperkirakan kuat tekan kubus beton untuk $\mathrm{W} / \mathrm{C}=0,5$ dapat ditetapkan. Dengan demikian tersusun pembagian tugas, di mana batang tulangan baja bertugas memperkuat dan menahan gaya tarik, sedangkan beton hanya diperhitungkan untuk menahan gaya tekan (Dipohusodo, 1993)

Beton didapat dari pencampuran bahan-bahan agregat halus dan agregat kasar yaitu pasir, batu pecah, atau bahan semacam lainnya, dengan menambahkan 
secukupnya bahan perekat semen, dan air sebagai bahan pembantu guna keperlun reaksi kimia selama peoses pengerasan dan perawatan beton berlangsung. Agregat halus dan kasar, disebut sebagai bahan susun kasar campuran, merupakan komponen utama beton. Nilai kekuatan serta daya tahan (durability) beton merupakan fungsi dari banyak faktor, diantaranya ialah nilai banding campuran dan mutu bahan susun, metode pelaksanaan pengecoran, pelaksanaan finising, temperatur, dan kondisi perawatan pengerasannya (Istimawan Dipohusodo, 1993).

Pada suatu kombinasi bagunan gedung, kolom berfungsi sebagai pendukung beban-beban dari balok dan pelat, untuk diteruskan ke tanah dasar melalui pondasi (Asroni, 2010).

\section{METODE}

Metode dalam pencampuran beton ada lebih dari satu diantaranya adalah metode Departement of Environment (DoE) yang tertuang di dalam SNI T:151991-03 yaitu "Tata Cara Pembuatan Rencana Campuran Beton Normal" Departement of Environment (DoE), Building Research Establisment, Britain (jurnal Arifal Hidayat). Merupakan adopsi dari cara Ukuran dasar pengaturan beton adalah kekuatan tekan beton yang berhubungan dengan air semen yang digunakan. Menurut Neville (1981) untuk mendapatkan kekuatan yang tinggi maka penggunaan air dalam campuran beton harus minimum

Bahan: unsur beton airsemen, agregat halus, dan agregat kasar yang telah memenuhi syarat. Peralatan: Timbangan, peralatan untuk membuat adukan (wadah, sendok, semen, peralatan pengukur slump, dan peralatan pengukur berat volume). Tujuan: Menentukan komposisi/unsur beton basa dengan ketentuan kekuatan tekan karakteristik dan slump rencana. Prosedur pemeriksaaan bahan dengan pemeriksaan mutu beton dan mutu pelaksanaan dan perancangan campuran beton dengan metode DoE.

\section{HASIL}

Pada metode Departement of Environment (DoE) ini penentuan besarnya semen yang diperlukan untuk $1 \mathrm{~m}^{3}$ beton didasarkan atas perbandingan berat air terhadap berat semen sebesar 0,5 sehubungan dengan kuat tekan kubus beton bersisi $150 \mathrm{~mm}$ untuk umur, tipe semen dan agregat kasar yang digunakan pada proses perancangan campuran. Dengan kata lain, penentuan faktor air semen sangat tergantung pada jenis agregat kasar yang digunakan, tipe semen serta umur beton dimana kekuatan tekannya akan ditinjau.

Tabel 1. Persyaratan gradasi agregat gabungan menurut BS 8821983

\begin{tabular}{|c|c|c|c|c|}
\hline \multirow{2}{*}{$\begin{array}{c}\text { Ukuran saringan } \\
(\mathrm{mm})\end{array}$} & \multicolumn{4}{|c|}{ Prosentase berat lolos ukuran saringan } \\
\cline { 2 - 5 } & $40 \mathrm{~mm}$ & $20 \mathrm{~mm}$ & $10 \mathrm{~mm}$ & $5 \mathrm{~mm}$ \\
\hline 50,0 & 100 & - & - & - \\
\hline 37,5 & $95-100$ & 100 & - & - \\
\hline 20,0 & $45-80$ & $95-100$ & - & - \\
\hline 14,0 & - & - & 100 & - \\
\hline 10,0 & - & - & $95-100$ & - \\
\hline 5,0 & $25-50$ & $35-55$ & $30-65$ & $70-100$ \\
\hline 2,36 & - & - & $20-50$ & $25-70$ \\
\hline
\end{tabular}




\begin{tabular}{|c|c|c|c|c|}
\hline 1,18 & - & - & $15-40$ & $15-45$ \\
\hline 0,60 & $8-30$ & $10-35$ & $10-60$ & $5-25$ \\
\hline 0,30 & - & - & $5-15$ & $3-20$ \\
\hline 0,15 & $0-8$ & $0-8$ & $0-8$ & $0-15$ \\
\hline
\end{tabular}

Catatan ; *Dapat ditingkatkan hingga 10\% untuk butiran halus dipecah

Guna menentukan komposisi campuran untuksetiap unit volume beton juga diperlukan data mengenai tingkat kemudahan pelaksanaan bagi jenis struktur yang bersangkutan dan ditunjukkan oleh besarnya nilai slump rencana. Pada metode Departement of Environment (DoE), besarnya slump rencana untuk berbagai tipe struktur dapat dilihat pada tabel 2 dibawah ini.

\begin{tabular}{|c|c|l|}
\hline $\begin{array}{c}\text { Tingkat kemudahan } \\
\text { pelaksanaan }\end{array}$ & $\begin{array}{c}\text { Slump } \\
(\mathrm{mm})\end{array}$ & \multicolumn{1}{|c|}{ Penggunaan beton cocok untuk } \\
\hline Sangat rendah & $0-25$ & $\begin{array}{l}\text { Jalan yang digetar dengan mesin penggetar } \\
\text { otomatis, dalam kasus tertentu dapat pula } \\
\text { digunakan mesin penggetar tanggan }\end{array}$ \\
\hline Rendah & $25-50$ & $\begin{array}{l}\text { Jalan yang digetar dengan mesin penggetar } \\
\text { tanggan, dalam kasus umum beton dapat } \\
\text { dipadatkan secara manual baik memakai } \\
\text { agregat bulat atau tak beraturan }\end{array}$ \\
\hline Sedang & $25-100$ & $\begin{array}{l}\text { Pelat lantai yang dipadatkan dengan } \\
\text { menggunakan agregat batu pecah. Beton } \\
\text { bertulang normal yang dipadatkan secara } \\
\text { manual dan penampang beton bertulang yang } \\
\text { digetar }\end{array}$ \\
\hline Tinggi & $100-175$ & \begin{tabular}{l} 
Penampang beton dengan tulangan rapat \\
\hline
\end{tabular} \\
\hline
\end{tabular}

Tabel 2 Nilai slump yang disyaratkan sesuai dengan penggunaan beton

Berbeda dengan metode sebelumnya, pada metode Departement of Environment (DoE) ini penentuan besarnya semen yang diperlukan untuk $1 \mathrm{~m}^{3}$ beton didasarkan atas perbandingan berat air terhadap berat semen sebesar 0,5 sehubungan dengan kuat tekan kubus beton bersisi $150 \mathrm{~mm}$ untuk umur, tipe semen dan agregat kasar yang digunakan pada proses perancangan campuran. Dengan kata lain, penentuan faktor air semen sangat tergantung pada jenis agregat kasar yang digunakan tipe semen serta umur beton dimana kekuatan tekannya akan ditinjau.

Untuk lebih jelasnya, maka besarnya perkiraan kekuatan tekan beton bagi faktor air semen sebesar 0,5 seperti terlihat pada tabel berikut telah disusun guna membantu dalam menentukan faktor air semen untuk kekuatan tekan yang direncanakan.

Tabel 3. Perkiraan kekuatan tekan beton dengan faktor air semen (W/C) $=0,5$

\begin{tabular}{|l|l|c|c|c|c|}
\hline Tipe Semen & Jenis Agregat & \multicolumn{4}{|c|}{ Kekuatan Tekan ( MPa ) pada Umur (hari) } \\
\cline { 2 - 6 } & Kasar & 3 hari & 7 hari & 28 hari & 91 hari \\
\hline Tipe I & Tidak Dipecah & 17 & 23 & 30 & 40 \\
\hline
\end{tabular}

604 BRILIANT: Jurnal Riset dan Konseptual Volume 4 Nomor 4, November 2019 


\begin{tabular}{|l|l|l|l|l|l|}
\hline & Dipecah & 19 & 27 & 34 & 45 \\
\hline \multirow{2}{*}{ Tipe III } & Tidak Dipecah & 21 & 28 & 38 & 44 \\
\cline { 2 - 6 } & Dipecah & 25 & 33 & 44 & 48 \\
\hline
\end{tabular}

Dengan telah ditetapkannya niali W/C, maka kualitas semen yang dibutuhkan dalam perencanaan dapat dihitung dengan menggunakan data banyaknya air bebas yang diperlukan untuk setiap kubikasibeton, seperti tabel berikut:

Tabel 4. Perkiraan jumlah air bebas yang diperlukan untuk memberikan tingkat workability tertentu

\begin{tabular}{|c|c|c|c|c|c|}
\hline \multirow{2}{*}{$\begin{array}{c}\text { Ukuran } \\
\text { Maksimum }\end{array}$} & \multicolumn{4}{|c|}{ Jenis Air $\left(\mathrm{kg} / \mathrm{m}^{3}\right)$ untuk } \\
\cline { 3 - 6 } $\begin{array}{c}\text { Agregat } \\
(\mathrm{mm})\end{array}$ & Jenis Agregat & \multicolumn{4}{|c|}{ Slump (mm) } \\
\cline { 3 - 6 } & & $0-10$ & $10-30$ & $30-60$ & $60-180$ \\
\hline \multirow{2}{*}{10} & Tidak Dipecah & 150 & 180 & 205 & 225 \\
\cline { 2 - 6 } & Dipecah & 180 & 205 & 230 & 250 \\
\hline \multirow{2}{*}{20} & Tidak Dipecah & 135 & 160 & 180 & 195 \\
\cline { 2 - 6 } & Dipecah & 170 & 190 & 210 & 225 \\
\hline \multirow{2}{*}{40} & Tidak Dipecah & 115 & 140 & 160 & 175 \\
\cline { 2 - 6 } & Dipecah & 155 & 175 & 190 & 205 \\
\hline
\end{tabular}

Besarnya jumlah semen yang dihitung atas dasar jumlah air bebas dan W/C yang sebelumnya telah ditetapkan, tidak boleh kurang dari jumlah semen minimum yang disyaratkan pada kondisi "exposure"tertentu untuk menjamin ketahanan pada kondisi yang disyaratkan seperti pada tabel berikut:

Tabel 5. Jumlah semen minimum untuk kondisi terekspos

\begin{tabular}{|l|l|l|l|l|l|}
\hline Kondisi Ekspos & \multicolumn{5}{|c|}{ Selimut Beton (mm) } \\
\hline Ringan & 25 & 20 & 20 & 20 & 20 \\
\hline Sedang & - & 35 & 30 & 25 & 20 \\
\hline Buruk & - & - & 40 & 30 & 25 \\
\hline Sangat Buruk & - & - & 50 & 40 & 30 \\
\hline Ekstrim & - & - & - & 60 & 50 \\
\hline W/C maksimum & 0,65 & 0,60 & 0,55 & 0,50 & 0,45 \\
\hline Jumlah sememn minimun $\left(\mathrm{kg} / \mathrm{m}^{3}\right)$ & 275 & 300 & 325 & 350 & 400 \\
\hline Kekuatan minimun $(\mathrm{MPa})$ & 30 & 35 & 40 & 4 & 50 \\
\hline
\end{tabular}

Langkah selanjutnya dari perancangan beton dengan metode DOE ini adalah memperkirakan berat jenis beton segar dengan memanfaatkan data jumlah air bebas dan specific garvity agregat gabungannya. Untuk memperkirakan besarnya berat jenis beton segar, guna menentukan jumlah masing-masing agregat untuk $1 \mathrm{~m}^{3}$ beton, terlebih dahulu dibutuhkan prosentase masing-masing agregat sehingga langkah untuk memperkirakan berat jenis beton segar dapat dilakukan.

Perkiraan prosentase masing-masing agregat dalam satu unit beton dapat ditempuh dengan memanfaatkan grafik hubungan antara besarnya faktor air semen (W/C) dengan prosentase agregat halus untuk beberapa nilai slump dan ukuran maksimum agregat yang dipakai yang dapat dilihat pada gambar berikut: 

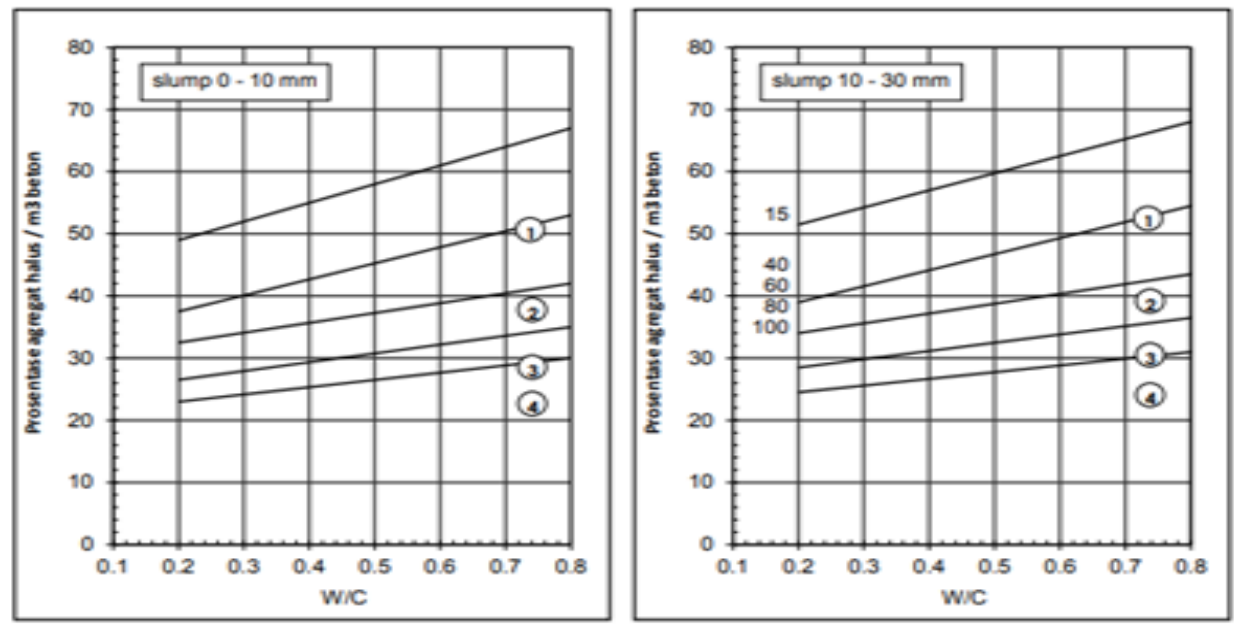

Gambar 1. Penentuan prosentase agregat halus untuk diameter maksimum $10 \mathrm{~m}$
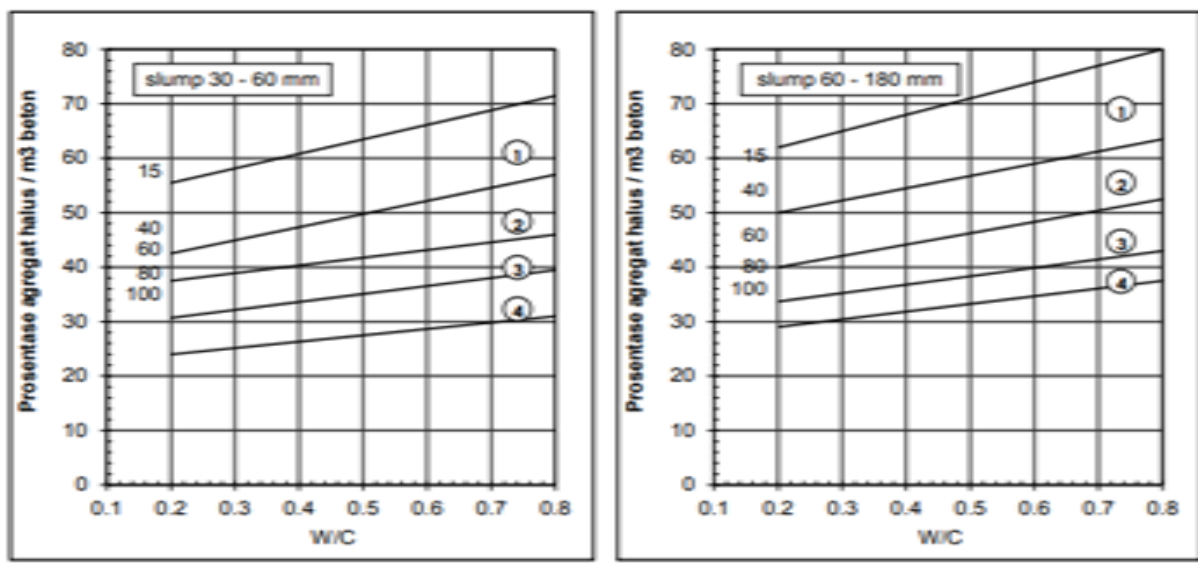

Gambar 2. Penentuan prosentase agregat halus untuk diameter maksimum $10 \mathrm{~mm}$
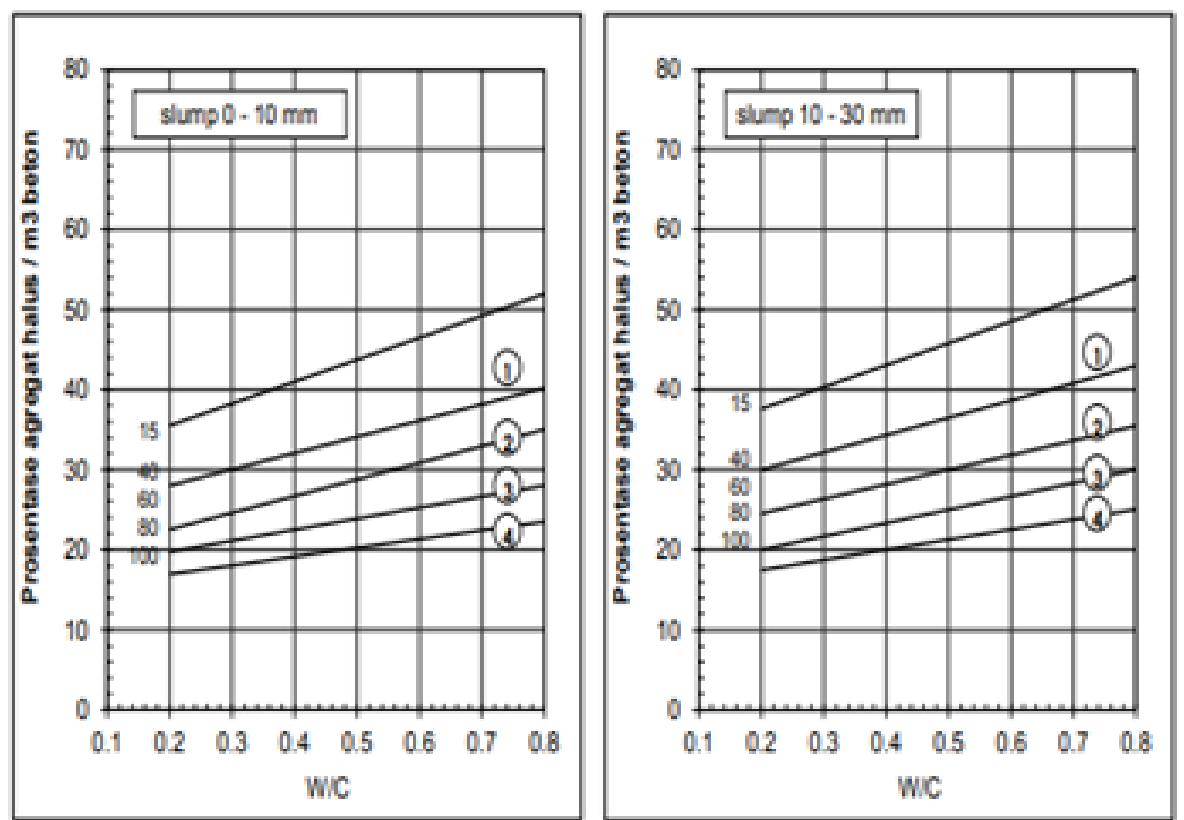

Gambar 3. Penentuan prosentase agregat halus untuk diameter maksimum $20 \mathrm{~mm}$ 

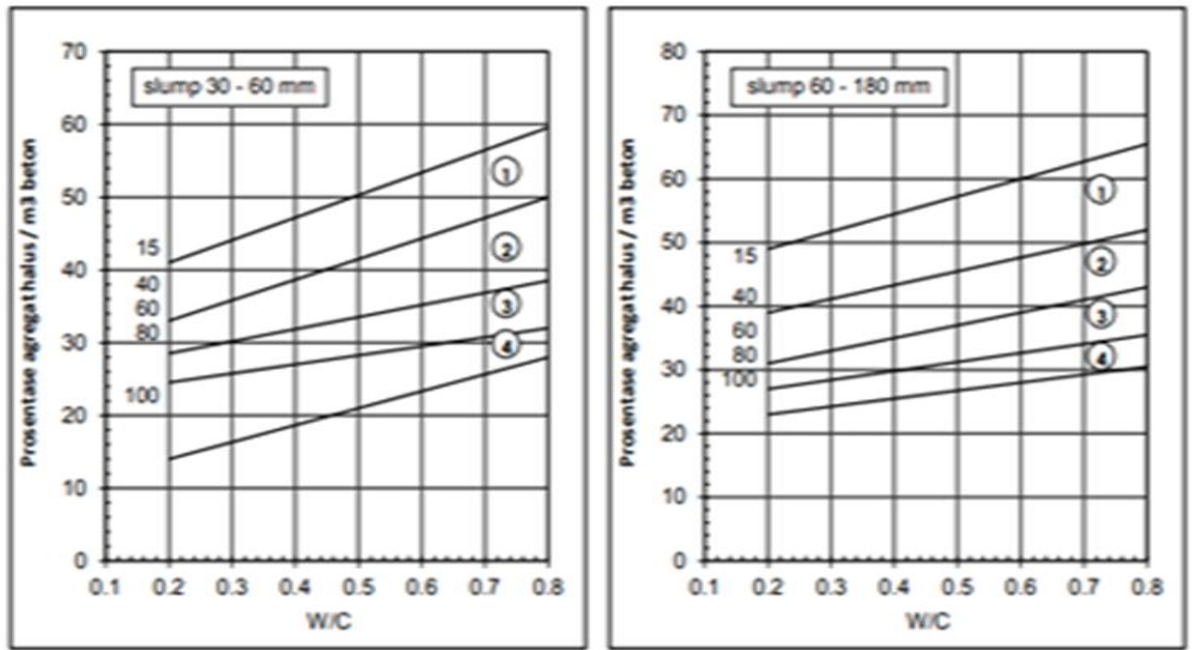

Gambar 4. Penentuan prosentase agregat halus untuk diameter maksimum $20 \mathrm{~mm}$
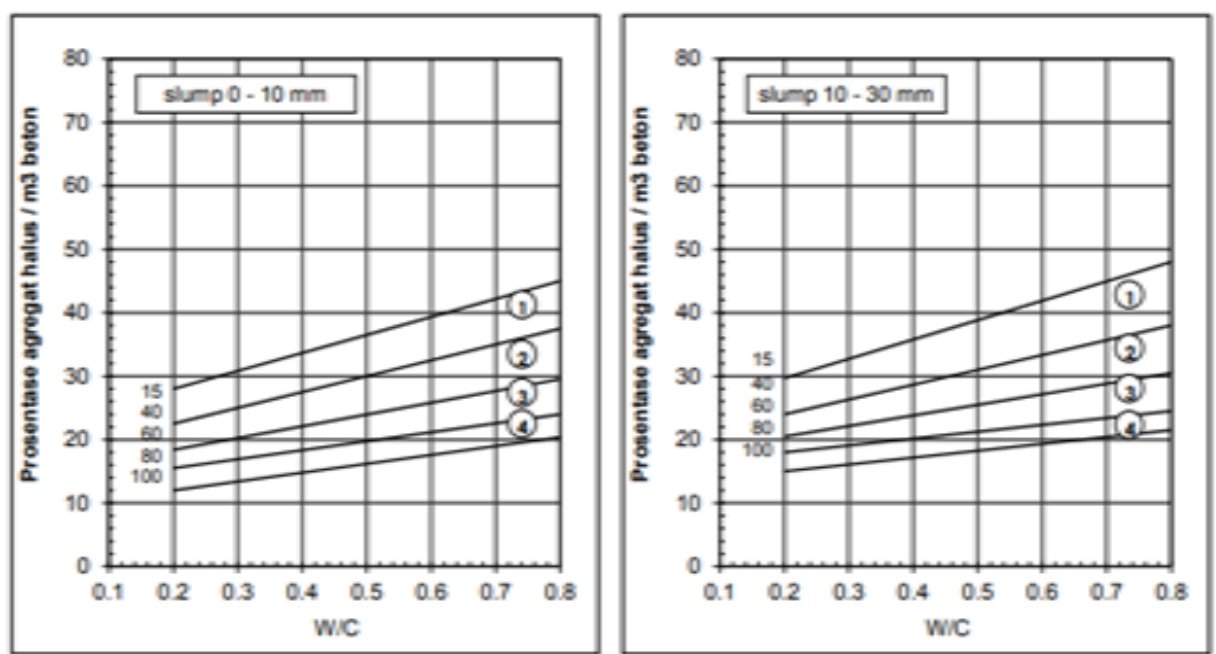

Gambar 5. Penentuan prosentase agregat halus untuk diameter maksimum $40 \mathrm{~mm}$

\section{PEMBAHASAN}

Menentukan kuat tekan rata - rata $: f^{\prime} c=15$

\begin{tabular}{|l|c|c|c|c|}
\hline \multicolumn{2}{|c|}{ Isi Pekerjaan } & \multicolumn{3}{c|}{ Deviasi Standart S (MPa) } \\
\hline Sebutan & $\begin{array}{c}\text { Jumlah } \\
\text { Beton }\left(\mathrm{m}^{3}\right)\end{array}$ & Baik Sekali & Baik & Dapat Diterima \\
\hline Kecil & $<1000$ & $4,5<\mathrm{S}<5,5$ & $5,5<\mathrm{S}<6,5$ & $6,5<\mathrm{S}<8,5$ \\
\hline Sedang & $1000-3000$ & $3,5<\mathrm{S}<4,5$ & $4,5<\mathrm{S}<5,5$ & $5,5<\mathrm{S}<7,5$ \\
\hline Besar & $>3000$ & $2,5<\mathrm{S}<3,5$ & $3,5<\mathrm{S}<4,5$ & $4,5<\mathrm{S}<6,5$ \\
\hline
\end{tabular}

$$
\begin{aligned}
\text { F'cr }^{\prime} & =f^{\prime} \mathrm{c}+1,34 . \mathrm{S} \\
& =15+1,34.6 \\
& =23,04 \mathrm{Mpa}
\end{aligned}
$$

$\mathrm{F}^{\prime} \mathrm{cr}=\mathrm{f}^{\prime} \mathrm{c}+2,33 . \mathrm{S}-3,5$ 


$$
\begin{aligned}
= & 15+2,33.6-3,5 \\
= & 25,48 \mathrm{Mpa} \\
& \text { yang diambil yang terbesar } 25,48 \mathrm{Mpa}
\end{aligned}
$$

Menentukan faktor air semen (f.a.s) menggunakan tabel 1

\begin{tabular}{|l|l|c|c|c|c|}
\hline \multirow{2}{*}{ Tipe Semen } & Jenis Agregat & \multicolumn{4}{|c|}{ Kekuatan Tekan ( MPa ) pada Umur (hari) } \\
\cline { 2 - 6 } & Kasar & 3 hari & 7 hari & 28 hari & 91 hari \\
\hline \multirow{2}{*}{ Tipe I } & Tidak Dipecah & 17 & 23 & 30 & 40 \\
\cline { 2 - 6 } & Dipecah & 19 & 27 & 34 & 45 \\
\hline \multirow{2}{*}{ Tipe III } & Tidak Dipecah & 21 & 28 & 38 & 44 \\
\cline { 2 - 6 } & Dipecah & 25 & 33 & 44 & 48 \\
\hline
\end{tabular}

$\mathrm{w} / \mathrm{c}=0,5 \quad$ f.a.s $=0,6$

Menentukan kadar air bebas

\begin{tabular}{|c|c|c|c|c|c|}
\hline \multirow{2}{*}{$\begin{array}{c}\text { Ukuran } \\
\text { Maksimum } \\
\begin{array}{c}\text { Agregat } \\
(\mathrm{mm})\end{array}\end{array}$} & \multirow{2}{*}{ Jenis Agregat } & \multicolumn{4}{|c|}{ Jenis Air $\left(\mathrm{kg} / \mathrm{m}^{3}\right)$ untuk } \\
\cline { 3 - 6 } & & $0-10$ & $10-30$ & $30-60$ & $60-180$ \\
\cline { 3 - 6 } & Tidak Dipecah & 150 & 180 & 205 & 225 \\
\cline { 2 - 6 } & Dipecah & 180 & 205 & 230 & 250 \\
\hline \multirow{2}{*}{20} & Tidak Dipecah & 135 & 160 & 180 & 195 \\
\cline { 2 - 6 } & Dipecah & 170 & 190 & 210 & 225 \\
\hline \multirow{2}{*}{40} & Tidak Dipecah & 115 & 140 & 160 & 175 \\
\cline { 2 - 6 } & Dipecah & 155 & 175 & 190 & 205 \\
\hline
\end{tabular}

Gunakan tabel 2 yang dibuat untuk agregat gabungan alami (tidak pecah)dengan agregat yang dipecah.Sesuai tabel 5, dengan menggunakan ukuran maksimum agregat 40, dengan nilai slump 60-180, didapatkan $\mathrm{Wf}=175$, dan $\mathrm{Wc}$ $=205$.

Untuk agregat gabungan yang berupa campuran antara pasir alami dan kerikil (batu pecah) maka kadar air bebas diperitungkan dengan rumus:

$$
\mathrm{W}=\frac{2}{3} \mathrm{wf}+\frac{1}{3} \mathrm{wc}=\frac{2}{3} 175+\frac{1}{3} 205=185 \mathrm{~kg} / \mathrm{m}^{3}
$$

Dimana : $\quad$ Wf $=$ kadar air bebas untuk agregat alami (tidak pecah)

\section{Menentukan Jumlah Semen}

$$
\mathrm{Wc}=\text { kadar air bebas untuk agregat yang pecah }
$$

Jumlah Semen PC = jumlah air bebas / faktor air semen

\section{Menetukan Presentase Agregat Halus}

$$
\mathrm{W} / \mathrm{f} . \mathrm{a} . \mathrm{s}=185 / 0,62=298,387 \mathrm{~kg} / \mathrm{m} 3
$$

Dengan menggunakan grafik no $14 \mathrm{c}$ yang didasarkan atas zone pasir, f.a.s : nilai slumpdan diameter agregat maksimum, dan hasil akhir dari penggunaan grafik ini adalah presentase pasir.

Diketahui: - $\quad \mathrm{W} / \mathrm{C}=0,62$

- Presentase agregat halus $=43 \%$

- Presentase agregat kasar $=100 \%-43 \%=57 \%$ 


\section{Menentukan Berat Jenis Beton Segar}

Dari jumlah air bebas W dan specific gravity gabungan Gs gab, perkiraan berat jenis beton segar sebesar D.

Diketahui

\section{berat jenis agregat gabungan}

$$
\begin{gathered}
=\frac{(\% \text { halus X Bj halus SSD })+(\% \text { kasar X Bj kasar SSD })}{100 \%} \\
=\frac{(43 \% 6 \times 2,703)+(57 \% \times 2,585)}{100 \%} \\
=2,6
\end{gathered}
$$

\section{Menentukan jumlah agregat kondisi SSD}

a. Total Agregat = BJ beton segar - jumlah semen $-\mathrm{W}$

$$
\begin{aligned}
& =2380-298,387-185 \\
& =1896,613 \mathrm{~kg} / \mathrm{m}^{3}
\end{aligned}
$$

b. Jumlah Agregat Halus = presentase agregat halus $\mathrm{x}$ total agregat

$$
\begin{aligned}
& =43 \% \times 1896,613 \\
& =815,544 \mathrm{~kg} / \mathrm{m}^{3}
\end{aligned}
$$

c. Agregat Kasar = presentase agregat halus $\mathrm{x}$ total agregat

$$
\begin{aligned}
& =57 \% \text { x } 1896,383 \\
& =1081,069 \mathrm{~kg} / \mathrm{m}^{3}
\end{aligned}
$$

\section{Menentukan komposisi campuran kondisi di lapangan}

a. Semen $=298,387 \mathrm{~kg} / \mathrm{m}^{3}$

b. Agregat kasar (asli) $\quad=\frac{100+w c \text { asli }}{100+w c \text { SSD }} \times$ agregat kasar SSD

c. Agregat kasar (asli) $=\frac{100+\text { wc asli }}{100+\text { we SSD }} \mathrm{x}$ agregat kasar SSD

1. Kebutuhan air lapangan

$$
\begin{aligned}
& =\frac{100+7,907}{100+0,9915} \times 815,544 \\
& =871,4 \mathrm{~kg} / \mathrm{m}^{3}
\end{aligned}
$$

Air $=\mathrm{W}+$ (jumlah agregat halus SSD - Jumlah agregat halus asli $)+$ (jumlah agregat kasar SSD- jumlah agregat kasar asli)

$=185+(815,544-871,4)+(1081,069-1078,14)$

$=132,073 \mathrm{~kg} / \mathrm{m}^{3}$

2. Menghitung kebutuhan cor

\section{Silinder}

$$
\begin{array}{ll}
\text { Volume silinder } & =\pi \cdot r^{2} \cdot \mathrm{t} \\
& =3,14 \times 0,075^{2} \times 0,3 \\
& =0,005299 \mathrm{~m}^{3}- \\
& =0,005299 \times 8 \\
& =0,04239 \mathrm{~m}^{3}
\end{array}
$$

Faktor kehilangan $=1,2$

Kebutuhan untuk silinder: 


$\begin{array}{ll}\text { Semen } & =0,04239 \times 298,387 \times 1,2=15,179 \mathrm{~kg} \\ \text { Pasir } & =0,04239 \times 871,4 \times 1,2=44,328 \mathrm{~kg} \\ \text { Kerikil } & =0,04239 \times 1078,14 \times 1,2=54,845 \mathrm{~kg} \\ \text { Air } & =0,04239 \times 132,073 \times 1,2=6,718 \mathrm{~kg}\end{array}$

\section{Balok}

Volume balok $=\mathrm{P} \times \mathrm{L} \times \mathrm{T}$

$$
\begin{aligned}
3 \text { balok } & =0,6 \times 0,15 \times 0,15=0,0135 \mathrm{~m}^{3} \text {---------(untuk } 1 \text { balok) } \\
& =0,0135 \times 3=0,027 \mathrm{~m}^{3}
\end{aligned}
$$

Faktor kehilangan $=1,2$

Kebutuhan untuk balok:

\begin{tabular}{|c|c|c|}
\hline Semen & $=15,179+9,668$ & $=24,847 \mathrm{~kg}$ \\
\hline Pasir & $=44,328+28,233$ & $=72,561 \mathrm{~kg}$ \\
\hline Kerikil & $=54,845+34,932$ & $=89,777 \mathrm{~kg}$ \\
\hline Air & $=6,718+4,279$ & $=10,997 \mathrm{l}$ \\
\hline
\end{tabular}

$$
\begin{array}{ll}
\text { Semen } & =0,0027 \times 298,387 \times 1,2=9,668 \mathrm{~kg} \\
\text { Pasir } & =0,0027 \times 871,4 \times 1,2=28,233 \mathrm{~kg} \\
\text { Kerikil } & =0,0027 \times 1078,14 \times 1,2=34,932 \mathrm{~kg} \\
\text { Air } & =0,0027 \times 132,073 \times 1,2=4,279 \mathrm{~kg}
\end{array}
$$

Total kebutuhan campuran untuk cor:

\section{Menghitung kebutuhan Mortar}

Kubus

Volume Kubus $\quad=S^{3}$

$$
3 \text { kubus } \quad=3 \times 0,000125=0,000375 \mathrm{~m}^{3}
$$

Faktor keamanan $=2,2$

Kebutuhan untuk kubus:

$$
\begin{array}{ll}
\text { Semen } & =0,000375 \times 298,387 \times 2,2=0,246 \mathrm{~kg} \\
\text { Pasir } & =0,000375 \times 871,4 \times 2,2=0,719 \mathrm{~kg} \\
\text { Kerikil } & =0,000375 \times 1078,14 \times 2,2=0,889 \mathrm{~kg} \\
\text { Air } & =0,000375 \times 132,073 \times 2,2=0,109 \mathrm{~kg}
\end{array}
$$

Balok

$$
\begin{array}{ll}
\text { Volume Balok } & =\mathrm{P} \times \mathrm{L} \times \mathrm{T} \\
& =0,16 \times 0,04 \times 0,04=0,000256 \mathrm{~m}^{3}--- \text { (untuk } 1 \\
\begin{array}{l}
\text { Balok) } \\
3 \text { Balok }
\end{array} & =3 \times 0,000256=0,000768 \mathrm{~m}^{3}
\end{array}
$$

Faktor keamanan $=2,2$

Kebutuhan untuk balok:

$\begin{array}{ll}\text { Semen } & =0,000768 \times 298,387 \times 2,2=0,504 \mathrm{~kg} \\ \text { Pasir } & =0,000768 \times 871,4 \times 2,2=1,472 \mathrm{~kg} \\ \text { Kerikil } & =0,000768 \times 1078,14 \times 2,2=1,822 \mathrm{~kg} \\ \text { Air } & =0,000768 \times 132,073 \times 2,2=0,223 \mathrm{~kg}\end{array}$

Briquette

$$
\text { Volume Briquette } \quad=80 \mathrm{~cm}^{3}=0,00008 \mathrm{~m}^{3} \text {----(untuk } 1 \text { Briquette) }
$$


3 Briquette $\quad=3 \times 0,00008=0,00024 \mathrm{~m}^{3}$

Faktor keamanan $=2,2$

Kebutuhan untuk Briquette:

$\begin{array}{ll}\text { Semen } & =0,00024 \times 298,387 \times 2,2=0,158 \mathrm{~kg} \\ \text { Pasir } & =0,00024 \times 871,4 \times 2,2=0,46 \mathrm{~kg} \\ \text { Kerikil } & =0,00024 \times 1078,14 \times 2,2=0,569 \mathrm{~kg} \\ \text { Air } & =0,00024 \times 132,073 \times 2,2=0,07 \mathrm{~kg}\end{array}$

Total Kebutuhan campuran untuk mortar:

\begin{tabular}{|c|c|c|}
\hline Semen & $=0,246+0,504+0,158$ & $=0,908 \mathrm{~kg}$ \\
\hline Pasir & $=0,719+1,472+0,460$ & $=2,651 \mathrm{~kg}$ \\
\hline Kerikil & $=0,889+1,822+0,569$ & $=3,280 \mathrm{~kg}$ \\
\hline Air & $=0,109+0,223+0,07$ & $=0,402 \mathrm{~kg}$ \\
\hline
\end{tabular}

\section{KESIMPULAN}

Hasil perhitungan merancang campuran beton yaitu kebutuhan campuran untuk cor airnya adalah $10,997 \mathrm{~kg}$, kesimpulannya adalah kebutuhan air buat mortar lebih sedikit daripada kebutuhan air buat campuran untuk cor.

\section{SARAN}

Pemeriksaan kekutan beton biasanya dilakukan pada umur 3 hari, 7 hari, 14 hari dan 28 hari, minimal 2 buah benda uji untuk setiap pemeriksaan. Jadi semakin tinggi mutu beton maka kebutuhan air juga semakin sedikit.

\section{DAFTAR RUJUKAN}

Ali Ansori. (2010). Balok Pelat Beton Bertulang. Yogyakarta: Graha Ilmu Subiyanto. (1987). Kontruksi Beton Pratekan. Bandung: Cipta Offset Istimawan Dipohusodo. (1991). Sruktur Beton Betulang. Jakarta Berdasarkan SK.SNI T-15-1991-03 Departemen Pekerjaan Umum RI

Ali Asroni. (2010). Kolom Fondasi dan Balok T Beton Bertulang penerbit Yogyakarta: Grah Ilmu

Prof.Ir.Rachmat Purwono, M.Sc (2005) Perencanaan Struktur Beton Bertulang Tahan Gempa. Surabaya: ITS press

Dr. Edward G. Nawy, PE. (2010). Beton Bertulang -Suatu Pendekatan Dasar Bandung: Refika Aditama.

Prof. IR. Soemono. (1980). Nomogram Beton Bertulang. Bandung: Djambatan

Arifa Hidayat. (2012). Perbandingan Rancangan Campuran Beton antara Metode Doe dan ACI. Jurnal APTEK Vol.4 No. 2

SK SNI T-15-1991-03 Tata Cara Perhitungan Struktur Beton Untuk Bangunan (Gedung Departemen Pekerjaan Umum)

SNI 03-2847-2002 Tata Cara Perhitungan Struktur Beton untuk Bangunan Gedung (Beta Version)

SNI 4817:2008 Spesifikasi Lembaran Bahan Penutup untuk Perawatan Beton

SNI 4156:2008 Cara Uji Bliding dari Beton Segar

SNI 6369:2008 Tata Cara Pembuatan Kaping untuk Benda Uji Silinder Beton

SNI 3419:2008 Cara Uji Abrasi Beton di Laboratorium

SNI 3402:2008 Cara Uji Isi Beton Ringan Struktural

SNI 07-2052:2002 Baja Tulangan Beton 
SNI 2458:2008 Tata Cara Pengambilan Contoh Uji Beton Segar

SNI 1972:2008 Cara Uji Slump Beton

SNI 1973:2008 Cara Uji Berat Isi, Volume Produksi Campuran dan Kadar Udara

Beton

612 BRILIANT: Jurnal Riset dan Konseptual

Volume 4 Nomor 4, November 2019 